\title{
Kalite Kontrol Grafiklerinden "Shewart, Cusum ve Ewma” nın Bir Üretim İşletmesinde Uygulanması*
}

\author{
İrfan ERTUĞRUL ${ }^{1}$ Abdullah ÖZÇİL \\ Pamukkale Üniversitesi, İktisadi ve İdari Bilimler Fakültesi, İşletme Bölümü, DENIZLİ
}

\begin{abstract}
Özet
19. yy sanayi devrimi sonrasında ürün ve hizmet sektöründe rekabet piyasasının oluşması ile birlikte kalite kavramı doğmuştur. Üreticiler ve tüketiciler geçmişten günümüze kaynaklarını optimal düzeyde kullanmak istemeleri kalitenin gelişimine çok fazla katkıda bulunmuştur. Küresel rekabet ortamı ile işletmelerin ürün veya hizmet piyasasında var olmasında kalite kavramı çok fazla önem kazanmıştır. Bu çalışmanın amacı ürün veya hizmetlerin kalite seviyelerini arttırmaya yönelik kalite araçlarından kontrol grafiklerinin kullanımını örneklemektir. Yapılan çalışmada, hedeflenen kalite düzeyini tespit etmek amacıyla değişken nicelikler için kontrol grafikleri (SHEWART), kümülatif toplam kalite kontrol grafikleri (CUSUM) ve üstel ağırlıklı hareketli ortalama kontrol grafikleri (EWMA) kullanılmıștır. Farklı tür kontrol grafikleri kullanılarak aralarındaki farklılıklar sunulmuștur. Bakır sektöründe yapılan kontrol grafiği analizi yapılacak olan işletme uygulamalarına ve teorik çalışmalara yardımcı olacaktır.
\end{abstract}

Anahtar Kelimeler: Kalite, İstatistiksel Kalite Kontrol, Kontrol Grafiği Türleri, Shewart, Cusum, Ewma.

\section{An Application of "Shewart, Cusum and Ewma" Quality Control Charts into A Manufacturing Business}

\begin{abstract}
After the industrial revolution in the 19th century, the concept 'quality' was borned with the competition in the products and services industry. That producers and consumers from past to present want to use the resources at an optimal level has contributed so much to the quality development. Because of global competition, the concept 'quality' has gained much importance for the businesses to exist in the product or service market. The aim of this study is to sample the use of control charts which are the quality tools for increasing the levels of products or services. In the conducted study, in order to determine the level of aimed quality level, the control charts for variables (Shewart), cumulative sum quality control charts (CUSUM) and exponentially weighted moving average control charts (EWMA) are used. The differences among them are presented by using different control charts. The control chart for the copper industry will be helpful for the enterprise applications which will be held and theoretical studies.
\end{abstract}

Key Words: Quality, Statistical Quality Control, Control Chart Types, Shewart, Cusum, Ewma.

*Bu makale Abdullah ÖZÇİL'in Doç. Dr. İrfan ERTUĞRUL danışmanlığında hazırlamış olduğu "Shewart, Cusum ve Ewma Kontrol Grafiklerinin Bir Üretim İşletmesinde Uygulanması" isimli yüksek lisans tezinin uygulama bölümünden yararlanılarak hazırlanmıştır.

\section{Giriş}

Kalite artık insanların ekonomik ve sosyal hayatlarında tercihlerini yaparken kullandıkları, bireyler için farklı anlamlar taşıyabilen bir kavram haline gelmiştir. Kalite hayatın her alanında, sosyal yaşantıda, kamu hizmetlerinde var olmaya başlamıştır. Sadece tüketicilerin ekonomik anlamda yaptıkları tercihlerinde kullanılmak yerine kamu hizmetlerinin her alanında da aranılan bir özellik olmuştur. Böylece kalite her alanda varlığını sürdürmeye devam edecektir. Kalite kontrol grafikleri ve istatistiksel kalite kontrol grafikleri kullanımı sayesinde süreçlerin iyileştirilmesi ve kalitenin arttırılması kolaylaştırılmıştır. Sürece ilişsin değişkenlikler daha iyi gözlemlenebilir hale gelmiş ve önlem alınması kolaylaşmıştır. Ayrıca günümüz Toplam Kalite Yönetimi anlayışı içerisinde yer alacak temel istatistiksel kalite kontrol araçları istatistiksel kalite kontrol anlayışı olarak değerlendirilen dönemde keşfedilmeye başlanmıştır.
Uygulama bölümünde kontrol grafiği konusu olan bakır mamulüne ait direnç miktarı değişkenliği ve önemi anlatılmıştır. Farklı kontrol grafiği yöntemleri ile ürün değişkenliği değerlendirilmiştir. Farklı kontrol grafiği türleri arasında kıyaslama yapılabilmesi amacıyla eşit standartlarda değerlendirme yapılması hedeflenmiş ve öneriler sunulmuştur. Sonuç bölümünde ise uygulamaya ait kontrol grafiği seçim önerisinde bulunulmuş ve kullanılan farklı kontrol grafiği türleri karşılaştırılmıştır. İşletme yapısına uygun olabilecek kontrol grafiği farklılıkları ve uygulama kapsamındaki işletmenin kullanımına uygun Shewart kalite kontrol grafiği önerisi sunulmuştur.

\section{2. İstatistiksel Kalite Kontrol}

İstatistiksel kalite kontrol (İKK) üretim sürecindeki değişkenlerin en uygun kalite seviyesini belirlemesi, sistemin değerlendirilmesini ve sürecin izlenmesi için istatistiksel metotların uygulanması anlamına gelir. İKK yaygın olarak 
kullanılabilecek birçok problem çözme yöntemi anlamına da gelir. $\mathrm{Bu}$ yöntemlerin bazıları sürecin kontrolü veya izlenmesi ve karmaşı istatistiksel teorilerin kullanımı ile ilişkili değildir. Birçok alanda İKK bütün istatistik ve optimizasyon yöntemlerinin kalite geliştirme projelerinde ve diğer iş fonksiyonlarında kullanımı ile ilgilidir (Allen, 2006: 29). İKK statik değil dinamik bir kavramdır. Yani bir defa kurulduktan sonra sürekli ve adım adım gelişen ve genişleyen, mükemmeli arayan bir olgudur. Örneğin bir şirkette kontrol kartlarına dayanan bir kalite kontrol sistemi kurulduktan sonra, bununla yetinmeyip adım adım diğer kalite kontrol araçlarının uygulanmasına ve yerleştirilmesine çalışılmalıdır. Bunun en önemli nedeni müşterilerin gelişen isteklerine cevap vermek ve piyasada rekabet gücüne sahip olmaktır (Akkurt, 2002: 222).

İKK özel bir süreç yerine bütün bir örgütsel yaklaşımı tanımlamak için kullanılır. İKK bir süreci sürekli olarak izlemek ve potansiyel problemleri erkenden tespit etmek ve kalite iyileştirme müdahalelerinin etkisini değerlendirmek için bir araç olarak kullanılır (Nicolay vd., 2012: 328).

\section{3. İstatistiksel Kalite Kontrol Grafikleri}

İstatistiksel süreç kontrol teknikleri ürün kalitesini geliştirmek ve süreçleri izlemek için endüstride yaygın şekilde kullanılmaktadır. Çeşitli kontrol grafikleri de süreç içerisindeki değişkenleri izlemek ve ürünlerin kalitesini düşüren kontrol dışı durumları tespit etmek için geliştirilmiştir (Noorossana and Vaghefi, 2006: 191). Günümüzde yaygın olarak kullanılan bazı kontrol grafiği türleri; Shewart Kontrol Grafiği, Mosum Kontrol Grafiği (Moving Sum), Ewma Kontrol Grafiği (Exponentially Weighted Moving Average) ve Cusum Kontrol Grafiği (Cumulative Sum)'dir (Russo vd., 2012: 36).

Uygulama kapsamına son yıllarda en çok kullanılan Shewart, Cusum ve Ewma kontrol grafikleri alınmıştır. Literatürde farklı alanlarda farklı yöntemler ile bu kontrol grafikleri kullanılmaktadır. Ou vd. (2012) Shewart, Cusum ve SPRT (Sequential Probability Ratio Test) olmak üzere kontrol grafiklerini 3 türde sinıflandırarak kontrol grafiklerinin duyarlılığını ve verimliliğini ölçen Performans Karşılaştırma İndeksi (Performance Comparison Index - PCI) ve üretim süreci ortalaması için uygun kontrol grafiği önerilerinde bulunan bir çalışma yapmıştır. Han vd. (2010) hastalık belirtileri tespitinde performansı arttırmak için poisson dağılımına sahip gözlemleri geçici istatistiksel tarama, Cusum ve Ewma kontrol grafikleri ile incelemişlerdir. Wu vd. (2010) sürece ilişkin ortalama ve varyans değişkenliğini daha iyi gösterebilecek bütünsel algoritma kullanılarak oluşturulan Cusum kontrol grafiği modeli ile standart Cusum kontrol grafiğini kıyaslayan bir çalışma sunmuştur. Nenes (2011) Shewart, Cusum ve Ewma kontrol grafiklerinin maliyetini düşürerek optimalliği sağlamak amaciyla değişken parametreleri sabitlemeye yönelik bir çalışma sunmuştur. Yang vd. (2011) değişkenleri normal dağ 1 lım özelliği göstermeyen süreçler için yeni bir parametrik olmayan Ewma işaret kontrol grafiği önerisinde bulunmuştur. Chen ve Shaw (2011) tedarik zinciri yönetiminde sıcaklık yönetimi için yapay sinir ağları, radyo frekansı ile tanımlama teknolojisi ve Ewma kontrol grafiklerini birleştiren bir otomasyon sistemi geliştirmiştir. Riaz vd. (2011) performansını geliştirdikleri Cusum kontrol grafikleri ile diğer Cusum kontrol grafiği türleri ve Ewma kontrol grafiği ile karşılaştırmasını yapmışlardır. Dai vd.
(2011) süreç hakkındaki bilgilere göre uyum sağlayan ve değişkenlikleri daha iyi gözlemleyebilen bir çok değişkenli Cusum kontrol grafiği önerisinde bulunmuşlardır. Patel ve Divecha (2011) süreçteki değişimleri ve hataları daha etkili tespit edebilmek için normal dağılım varsayımı altında Markov Zinciri yaklaşımından faydalanarak değiştirilmiş bir Ewma kontrol grafiği önerisinde bulunmuşlardır. Yang vd. (2012) bir değişkene ait ortalama ve varyans değişimini izlemek çin uygun kontrol grafiği seçimi için Shewart ve Cusum kontrol grafiği türlerini kıyaslamışlardır. Abbasi vd. (2012) kontrol grafiklerinin duyarlılığını artıran bir Cusum kontrol grafiği modeli ile Shewart, Ewma, standart Cusum ve Comb kontrol grafiklerini kıyaslayan bir çalışma sunmuştur. Maravelakis (2012) ölçüm hatalarının Cusum ve Ewma kontrol grafikleri üzerindeki etkisini incelemiştir.

\subsection{Shewart Kontrol Grafikleri}

Shewart kontrol grafikleri istatistiksel kalite kontrolün temel araçlarındandır. $\mathrm{Bu}$ grafikler hem süreçlerin hassasiyetini ölçmede hem de endüstriyel süreçlerde devredilebilir nedenlerin oluşumunu tespit etmede yararlıdır (Topalidou and Psarakis, 2009: 773). Bir Shewhart grafiği merkez hattı ve orta çizginin altında ve üstünde belirli bir mesafede ayarlanmış bir alt ve üst kontrol limiti olan gözlemlerin gösterildiği bir zaman sıralı grafik ekranıdır (Vries ve Conlin, 2005: 320).

- $x$ Kontrol Grafiği Parametreleri

Bilinmeyen kitle parametrelerinin tahmincileri $\mu$ 'nün yansız tahmincisi $\bar{x}$, k alt grup sayısı olmak üzere:

$\overline{\bar{x}}=\frac{\sum \bar{x}_{i}}{k},(i=1,2,3, \ldots, k)$

$\bar{R}=\frac{\sum R_{i}}{k},(i=1,2,3, \ldots, k)$

Kalite kontrol grafiği sınır çizgileri çizilirken kullanılan sabit faktör değerleri $\left(A, A_{2}, B_{1} \ldots v b . g i b i\right)$ kontrol değişkenleri için kullanılan faktör değerleri tablosu yardımıyla elde edilmiştir. Uygulamada kullanılan anakütle ortalaması ve standart sapması bilinmediği durumlarda $\bar{x}$ kontrol grafiği parametreleri (Baskan, 1997: 68-71):

$\ddot{U}$ st Kontrol Limit $(\ddot{U} K L)=\overline{\bar{x}}+A_{2} \bar{R}=\overline{\bar{x}}+A \bar{s}$

Orta Çizgi $(O C ̧)=\overline{\bar{x}}$

Alt Kontrol Limiti $(A K L)=\overline{\bar{x}}-A_{2} \bar{R}=\overline{\bar{x}}-A \bar{s}$

Örneklem içerisinde yer alan alt grup ortalamalarının kontrol limitleri arasında kalması, ürünün kalitesi için bir ölçü olmakla birlikte, uygulamada çoğu zaman diğer bir ölçüye daha ihtiyaç duyulur. Örnek ortalaması istenen standartlara uyduğu halde, örnek içindeki birimlerde standarttan önemli ölçüde sapmalar görülebilir. Bu durumda aynı ortalamaya sahip olan iki örnekten standart sapması (s) veya değişim aralığı (R) daha küçük olan örneğin daha kaliteli olduğu söylenir. O halde ortalamanın kontrol limitleri yanında, s veya $\mathrm{R}$ için de benzer limitler çizilmeli ve üretimde hem kararlılık hem de değişim durumunun istenen limitler arasında kalması hedef alınmalıdır (Bostan, 2010: 40).

\section{- $\quad$ kontrol Grafiği Parametreleri}

Anakütle veya örneklem içerisinde yer alan minimum ve maksimum değer arasındaki farka değişim aralığ 1 denir ve $R$ harfi ile gösterilir. Eşitlik 6 yardımıyla hesaplanmaktadır (Montgomery, 2005: 197).

$R_{j}=x_{\max }-x_{\min }$

Her biri $\mathrm{n}$ birimden oluşan $\mathrm{m}$ tane örnek alındığında, $\mathrm{R}_{1}, \mathrm{R}_{2}, \ldots, \mathrm{R}_{\mathrm{m}}$ bu örneklerin değişim aralıkları olmak üzere 
değişim aralıkları ortalaması Eşitlik 7 yardımıyla hesaplanmaktadır (Şentürk, 2002: 25).

$\bar{R}=\frac{1}{m} \sum_{j=1}^{m} R_{j}$

Uygulamada kullanılan anakütle standart sapması bilinmediği durumlarda $\mathrm{R}$ kontrol grafiği parametreleri ise aşağıdaki eşitliklerde gösterilmiştir (Montgomery, 2005: 197).

$\ddot{U} K L=D_{4} \bar{R}$
$O C \zeta=\bar{R}$
$A K L=D_{3} \bar{R}$

\subsection{Cusum Kontrol Grafikleri}

Kümülatif toplam (Cumulative Sum) kontrol grafiği (Cusum veya CSCC), Shewart kontrol grafiklerinin örneklem ortalamalarındaki küçük ancak sürekli kaymalara karşı duyarsızlığ1 nedeniyle, bu grafiklere alternatif olarak geliştirilen dört grafik türünden birisidir. Cusum grafiği ilk kez Page (1954) tarafindan önerilmiş ve daha sonra Ewan (1963), Page (1961), Johnson (1961), Johnson ve Leone (1962) ve Lucas (1976) gibi pek çok yazar tarafından geliştirilmiştir (Işı̆̆ıçok, 2012: 289). Cusum kontrol grafiklerinde Barnhard (1959) tarafindan önerilen bir V maskesi kullanılmaktadır (Sun ve Kalbfleisch, 2013: 62). Bu sayede V maskesi ile üretim sürecinin kontrol sınırları belirlenmektedir.

\section{- Cusum kontrol grafiğinin çizimi}

Cusum kontrol grafiği örneklem değerlerinin hedef değerden cebirsel sapmalarının kümülatif toplamını $\left(\mathrm{S}_{\mathrm{i}}\right)$ grafik üzerine işaretleyerek örneklem verilerindeki bütün bilgiyi dikkate almaktadır. Ayrıca, Cusum kontrol grafikleri, küçük süreç kaymalarını belirlemek için birkaç örnekteki bilgiyi birleştirmeleri nedeniyle Shewart grafiklerinden daha üstündür. $\mathrm{Bu}$ üstünlük özellikle, $\mathrm{n}=1$ olan örneklem alt gruplarında daha etkilidir. $\mathrm{Bu}$ durum, Cusum kontrol grafiklerinin bir birimlik örnek alt grupları hacminin kullanıldığı kimya endüstrisinde ve her parçanın otomatik olarak ölçüldüğü ürünlerde ve bilgisayarlarla kontrol edilen ürünlerde yaygın olarak kullanılmasını sağlar. Ayrıca, süreç ortalamasından $0,5 \sigma$ gibi küçük bir kayma yerine daha büyük bir kayma $(1,5 \sigma$ veya $2 \sigma)$ olmasi durumunda, Shewart kontrol grafiklerinin daha etkili olacağını hatırlatılmalıdır (Işı ğıçok, 2012: 292). Endüstriyel istatistiksel kalite kontrol literatüründe Cusum grafikleri öznitelik verileri için Ewma kontrol grafiklerinden daha s1k önerilmiştir (Woodall, 2006: 91).

Bir X-rastgele değișkeni, $\mu$ ortalama ve $\sigma^{2}$ varyans ile normal dağılıma uyduğunda, bu kitleden alınacak örneklem ortalamalarının dağılımının da $\mu$ ortalama ve $\sigma^{2} / n$ varyans ile normal dağılıma uyacağı bilinir (Baskan, 1997: 273).

Cusum kontrol grafiği parametrelerinde kullanılan semboller ve anlamları aşağıda açıklanmıştır ve Şekil 1'de gösterilmiştir.

- $\alpha=$ Süreç ortalamasında bir kayma yok iken bir kaymanın olduğuna karar verme ihtimali

- $\beta=$ Gerçekte kayma var iken bunu tespit edememe ihtimali

- $\Delta=$ Süreç ortalamasında meydana gelen kayma miktar1

- $\mathrm{A}=$ Bir ölçek faktörüdür ve bu değer yatay eksen üzerindeki 1 birimlik uzunluğa dikey eksen üzerinde karşılık gelen değerdir. A değeri, $\sigma_{\bar{x}}$ ile $2 \sigma_{\bar{x}}$ arasında değişir ve bu değerin $2 \sigma_{\bar{x}}$ olarak alınması tercih edilir.
- $\delta=$ Araştırılmasına karar verilen süreç seviyesindeki en küçük kayma miktarını $\left(\Delta=\delta \sigma_{\bar{x}}\right)$

- $\sigma_{\bar{x}}$ ise örnek ortalamaları için standart hatayı $\left(\sigma_{\bar{x}}=\frac{\sigma}{\sqrt{n}}\right)$

- $\mathrm{H}=$ Prosedürün karar aralığı, OU ve OL uzunluğudur.

- $\mathrm{h}=$ Kendisiyle örnek istatistiğinin çarpılması durumunda karar aralığını veren değerdir. $H=\left(h \sigma_{\bar{x}}\right)$

- $\mathrm{K}=\mathrm{V}$ maskesi kollarının eğimidir.

- $\mathrm{k}=$ Kendisiyle örnek istatistiğinin çarpılması durumunda $\mathrm{V}$ maskesi kollarının eğimini veren değerdir $\left(K=k \sigma_{\bar{x}}\right)$.

- $\mathrm{d}=$ OP uzunluğunun değeri

- $\theta=$ Orta çizgi ile kol arasındaki açıyı verir (Demir, 2008: 17-18).

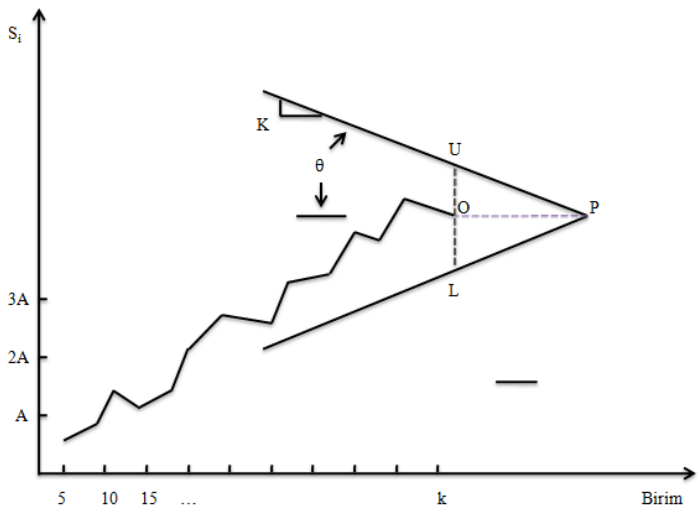

Şekil 1. V Maskesi Gösterimi (Kaynak: Oktay, 1994: 75)

Cusum (kümülatif toplam) kontrol grafiği parametreleri ise $\mathrm{S}_{\mathrm{i}}=\mathrm{i}$ 'nci birikimli değer, $\bar{x}_{j}=\mathrm{j}$ 'inci örneğin aritmetik ortalaması ve $k$ da hedeflenen değer olarak alınırsa, Eşitlik 11 'deki gibi hesaplanır.

$S_{i}=\sum_{j=1}^{i}\left(\bar{x}_{j}-k\right)$

$\mathrm{Bu}$ değeri, Cusum grafiklerinde kullanmak için Cusum eşitliği, Eşitlik 12'deki şekline dönüştürülür.

$S_{i}=\left(x_{i}-k\right)+S_{i-1}$

Çoğu kez, $k$ yerine dağılımın ortalaması $\overline{\bar{x}}$ alınır (Demir, 2008: 15).

- V maskesi prosedürü

Ĕger $\bar{x}_{i}$ 'nin standart sapması $\sigma_{\bar{x}}$ ile gösterilir, $\alpha$ ve $\beta$ 'nın da kabul edilir bir seviyede tutulması gerektiği düşünülürse, $\mathrm{V}$ maskesi parametreleri;

$d=\left(\frac{2}{\delta^{2}}\right) \operatorname{In}\left(\frac{1-\beta}{\alpha}\right)$

$\theta=\tan ^{-1}\left(\frac{\Delta}{2 A}\right)$

$\delta=\frac{\Delta}{\sigma_{\bar{x}}}$

Eğer $\beta$ değeri ihmal edilecek kadar küçük ise, $d$ değeri Eşitlik 16 'daki gibi yeniden düzenlenir.

$d=-2 \frac{\operatorname{In} \alpha}{\delta^{2}}$

Eldeki bilgiler ile Eşitlik 17 elde edilir.

$\tan \theta=\frac{\Delta}{2 A}=\frac{\delta \sigma_{\bar{x}}}{2\left(2 \sigma_{\bar{x}}\right)}=\frac{\delta}{4}$

Eşitlik 17 'deki gibi veya $K$ değerinin örnek aralık başına $\mathrm{V}$ maskesi kollarının eğimini vermesi ve $A$ 'nın Cusum ölçeğinde bir örnek aralığına eşit olması nedeniyle Eşitlik 18 de elde edilmiş olur. 
$\tan \theta=\frac{K}{A}=\frac{k \sigma_{\bar{x}}}{2 \sigma_{\bar{x}}}=\frac{k}{2}$

Eşitlik 17 ve 18 birbirine eşitlenirse, Eşitlik 19 ve 20 elde edilir.

$\frac{k}{2}=\frac{\delta}{4} \Rightarrow k=\frac{\delta}{2}$

$K=k \sigma_{\bar{x}}=\frac{\delta}{2} \sigma_{\bar{x}}=\frac{\Delta}{2}$

17).

Sonuç olarak Eşitlik 21 de yazılabilir (Demir, 2008: 16-

$\tan \theta=\frac{H}{A . d}=\frac{h \sigma_{\bar{\chi}}}{\left(2 \sigma_{\bar{\chi}}\right) d}=\frac{h}{2 d}$

\subsection{Ewma Kontrol Grafikleri}

Basit Ewma kontrol grafikleri yaklaşık olarak Cusum kontrol grafikleri ile eşdeğer etkiye sahiptir. Zaman serileri tahmini için yaygın olarak aynı teknolojiyi kullanmalarına rağmen her ikisi de henüz çok popüler değildir. Bu grafik türü özellikle etkili küçük alt grup büyüklügü̈nde düzenlenen bireysel grafik türleri için uygundur (Cusum grafiklerinde olduğu gibi) (Trietsch, 1999: 218).

Ewma kontrol grafikleri, süreç kontrolünün dışında zaman serilerinin analizinde ve tahminlerde sıklıkla kullanılmaktadır. Ewma, tüm geçmişin ve mevcut gözlemin ağırlıklandırılmıs ortalaması olarak düşünülebilmektedir. Bu nedenle normallik varsayımına karşı duyarsızdır ve alt örnek hacminin bire eşit olduğu durumlar için de idealdir (Y1lmaz, 2012: 22).

Örneklem hacmi $\mathrm{n}$, örneklem ortalamaları $\bar{X}_{j}(j=$ $1,2,3, \ldots, t, \ldots, k)$ ve $\overline{\bar{x}}=\frac{\sum_{1}^{k} \bar{x}_{j}}{k}$ olmak üzere t döneminin üstel ağırlıklı hareketli ortalaması Eşitlik 22'de gösterilen şekilde hesaplanır (Trietsch, 1999: 218).

$Z_{t}=\lambda \bar{X}_{t}+(1-\lambda) Z_{t-1}$

$$
\text { İlk Ewma değeri } \mathrm{t}=1 \text { için }
$$

$Z_{0}=\overline{\bar{x}}$ (Örneklemdeki alt örnek birimlerin ortalaması)'dır.

Grafiklerin kontrol sinırlarının hesaplanmasında standart sapma kullanılacağından $\mathrm{Z}_{\mathrm{t}}$ değerinin standart sapması Eşitlik 23 'te gösterilmiştir.

$\sigma_{Z_{t}}=\sigma \sqrt{\frac{\lambda}{(2-\lambda) n}}$

Eşitlik 23'te yer alan $\sigma$ 'nın bilinmemesi durumunda Eşitlik 24'te yer alan formüller kullanılarak standart sapma tahmin edilir (Işı̆̆ıçok, 2012: 307-308).

$s=\frac{\bar{R}}{d_{2}}=\frac{\bar{s}}{c_{4}}$

Uygulamada kullanılan anakütle ortalaması ve standart sapması bilinmemesi durumunda kontrol sinırları (Oktay, 1994: 121):

$\ddot{U} K L=\overline{\bar{x}}+A_{2} \bar{R} \sqrt{\frac{\lambda}{(2-\lambda)}}$

$O C=\overline{\bar{x}}$

$A K L=\overline{\bar{x}}-A_{2} \bar{R} \sqrt{\frac{\lambda}{(2-\lambda)}}$

- $\lambda$ parametresinin seçimi

Ewma kontrol grafikleri bellekli kontrol grafiği grubuna aittir. Üstel yumuşatma parametresinin $\lambda$ yüksek belirlenmesi önceki örneklerin etkisini düşürecektir
(Fleischer vd., 2008: 523). Üstel yumuşatma tahminin $\lambda=1$ olarak belirlendiği zaman Ewma değeri en son gözlem değerine bağlı olacaktır. Yani, Ewma değerinin belirlenmesinde önceki gözlemlerin hiçbir etkisi olmayacaktır. Roberts (1959), Crowder (1987) ve LucasSaccucci (1987) ortalama seviyesindeki kaymaların tespitinde, büyük $\lambda$ değerlerinin büyük çaptaki kaymaları tespitte ve küçük $\lambda$ değerlerinin süreç seviyesindeki küçük kaymaların tespitinde optimal sonuçları sağladığını göstermişlerdir (Oktay, 1994: 123).

\section{Uygulama}

\subsection{Uygulamanın Amacı}

Uygulama kapsamına alınan bakır üretim işletmesinden elde edinilen bilgiler 1şığında bobin üretim sürecindeki değişkenliğin azaltılması hedeflenmiştir. TKY içerisinde yer alan istatistiksel kalite kontrol araçlarından kontrol grafikleri kullanılarak üretim süreci değişkenliğinin azaltılması ve maksimum faydayı sağlayacak kontrol grafiği seçim önerisinde bulunulması amaçlanmıştır.

\subsection{Uygulamanın Yöntemi}

Uygulama aşamasında teorik bilgiler ve basit (tekli) örnekleme planı ile belirli zaman aralıklarında elde edinilen veriler birleştirilerek, farklı kontrol grafiği yöntemleri kıyaslanmıştır ve işletme açısından kalite düzeyinin arttırılması amacıyla öneriler de bulunulmuştur. Araştırmanın uygulama kısmında kalite kontrol grafiği çizmek için veriler Microsoft Excel 2007 programında hazırlanmıştır. Hazırlanan veriler ve WinQSB Version 1.0 programı ile literatürde en çok kullanılan Shewart, Cusum ve Ewma kontrol grafikleri çizilmiştir.

\subsection{Uygulamanın Konusu}

Uygulamanın konusu bakır mamulü bobin, elektronik devrelerde manyetik alan oluşturarak akım üzerinde değişiklik yapılmak amacıyla kullanılmaktadır. İstenilen özelliklerde sipariş isteğine göre üretilen bakır bobinler elektrik akımına karşı kullanılan hammadde veya işleme süreci değişkenliklerinden dolayı farklı direnç değerlerine sahip olabilmektedir. Bobinler elektronik devrelerin hammaddesi olarak kullanılması nedeniyle direnç değeri farklılığının kontrol altında olması hedeflenmektedir. Üretilen bobin ürünlerinin kullanıldığı alanlara: enerji santralleri, uzay endüstrisi, sağlık hizmetleri veya ulaştırma endüstrisi örnek gösterilebilir.

Denizli ilinde faaliyet gösteren, bakırın iletkenlik özelliğinin önemi açısından üretim işletmesine konu olan firmadan alınan veriler kalite çalışmalarında kullanılmak üzere kayıt altına alınmaktadır. İncelenen bobin ürününe ilişkin veriler firmanın kalite bölümünden elde edilmiştir. Bobin ürününe ait yıllık siparişlerdeki ölçülen direnç miktarları baz alınmıştır. Yılda 50 defa sipariş alınmış ve 10000 ürün teslim edilmiştir. Her örneğe ait 5 adet ürün ölçümünden oluşan 250 birimlik örneklem direnç miktarları Tablo 1'de verilmiştir.

Tablo 1. 5 Ürüne Ait 50 Örnek Grubuna Sahip Örneklem Ölçüm Değerleri

\begin{tabular}{|c|c|c|c|c|c|c|c|c|c|c|}
\hline $\begin{array}{l}\text { Örnek } \\
\text { Birim asar } \\
\text { No }\end{array}$ & 1 & 2 & 3 & 4 & 5 & 6 & 7 & 8 & 9 & 10 \\
\hline 1 & 15.220 & 15.220 & 15.257 & 15.225 & 15.250 & 15.236 & 15.258 & 15.220 & 15.230 & 15.228 \\
\hline 2 & 15.219 & 15.200 & 15.210 & 15.200 & 15.226 & 15.210 & 15.222 & 15.215 & 15.217 & 15.280 \\
\hline
\end{tabular}




\begin{tabular}{|c|c|c|c|c|c|c|c|c|c|c|}
\hline 3 & 15.124 & 15.141 & 15.137 & 15.143 & 15.152 & 15.122 & 15.079 & 15.114 & 15.100 & 15.097 \\
\hline 4 & 15.200 & 15.211 & 15.220 & 15.264 & 15.174 & 15.143 & 15.235 & 15.187 & 15.284 & 15.270 \\
\hline 5 & 15.166 & 15.146 & 15.176 & 15.144 & 15.155 & 15.165 & 15.140 & 15.140 & 15.200 & 15.196 \\
\hline Birim asax & 11 & 12 & 13 & 14 & 15 & 16 & 17 & 18 & 19 & 20 \\
\hline 1 & 15.232 & 15.253 & 15.242 & 15.272 & 15.219 & 15.105 & 15.092 & 15.090 & 15.275 & 15.253 \\
\hline 2 & 15.254 & 15.219 & 15.267 & 15.211 & 15.204 & 15.171 & 15.195 & 15.202 & 15.191 & 15.220 \\
\hline 3 & 15.103 & 15.112 & 15.099 & 15.117 & 15.073 & 15.180 & 15.173 & 15.190 & 15.191 & 15.200 \\
\hline 4 & 15.138 & 15.131 & 15.098 & 15.153 & 15.157 & 15.197 & 15.162 & 15.181 & 15.189 & 15.151 \\
\hline 5 & 15.205 & 15.223 & 15.193 & 15.203 & 15.192 & 15.221 & 15.194 & 15.158 & 15.120 & 15.174 \\
\hline $\begin{array}{l}\text { Örnek } \\
\text { No }\end{array}$ & 21 & 22 & 23 & 24 & 25 & 26 & 27 & 28 & 29 & 30 \\
\hline 1 & 15.260 & 15.186 & 15.227 & 15.277 & 15.217 & 15.259 & 15.270 & 15.298 & 15.220 & 15.206 \\
\hline 2 & 15.197 & 15.185 & 15.210 & 15.197 & 15.217 & 15.213 & 15.136 & 15.160 & 15.195 & 15.171 \\
\hline 3 & 15.203 & 15.219 & 15.118 & 15.131 & 15.206 & 15.232 & 15.200 & 15.200 & 15.216 & 15.236 \\
\hline 4 & 15.130 & 15.145 & 15.177 & 15.154 & 15.151 & 15.145 & 15.197 & 15.211 & 15.206 & 15.255 \\
\hline 5 & 15.189 & 15.186 & 15.140 & 15.220 & 15.150 & 15.187 & 15.178 & 15.196 & 15.174 & 15.184 \\
\hline $\begin{array}{l}\text { Örnek } \\
\text { Birim asar } \\
\text { No }\end{array}$ & 31 & 32 & 33 & 34 & 35 & 36 & 37 & 38 & 39 & 40 \\
\hline 1 & 15.187 & 15.240 & 15.260 & 15.250 & 15.232 & 15.242 & 15.207 & 15.220 & 15.214 & 15.144 \\
\hline 2 & 15.171 & 15.227 & 15.204 & 15.236 & 15.107 & 15.067 & 15.006 & 15.023 & 15.010 & 15.080 \\
\hline 3 & 15.263 & 15.134 & 15.203 & 15.207 & 15.228 & 15.198 & 15.261 & 15.226 & 15.216 & 15.155 \\
\hline 4 & 15.203 & 15.166 & 15.193 & 15.160 & 15.213 & 15.182 & 15.222 & 15.191 & 15.212 & 15.227 \\
\hline 5 & 15.180 & 15.280 & 15.120 & 15.138 & 15.207 & 15.240 & 15.285 & 15.201 & 15.212 & 15.185 \\
\hline $\begin{array}{l}\text { Örnek } \\
\text { No } \\
\text { No }\end{array}$ & 41 & 42 & 43 & 44 & 45 & 46 & 47 & 48 & 49 & 50 \\
\hline 1 & 15.147 & 15.147 & 15.160 & 15.193 & 15.242 & 15.233 & 15.240 & 15.168 & 15.167 & 15.219 \\
\hline 2 & 15.101 & 15.077 & 15.068 & 15.112 & 15.134 & 15.121 & 15.113 & 15.137 & 15.103 & 15.124 \\
\hline 3 & 15.163 & 15.120 & 15.152 & 15.130 & 15.012 & 15.189 & 15.226 & 15.220 & 15.214 & 15.211 \\
\hline 4 & 15.219 & 15.183 & 15.202 & 15.113 & 15.107 & 15.140 & 15.190 & 15.182 & 15.140 & 15.179 \\
\hline 5 & 15.199 & 15.199 & 15.199 & 15.185 & 15.169 & 15.152 & 15.212 & 15.181 & 15.212 & 15.182 \\
\hline
\end{tabular}

\subsection{Ortalamalar İçin Kontrol Grafikleri}

Uygulama kapsamına alınan bobin mamulüne ilişkin direnç miktarları farklı türdeki kalite kontrol grafikleri ve farklı değerlendirme yöntemleri ile incelenmiştir.

\subsubsection{Shewart Kontrol Grafiği Uygulaması}

Seçilen örneklemlere ilişkin standart Shewart kontrol grafiği uygulaması ortalamalar, değişim aralığı değerleri ve standart sapma değerleri ile birlikte hesaplanmıştır ve Tablo 2'de gösterilmiştir.

Tablo.2 Örneklem Ortalama, Değişim Aralığ 1 ve Standart Sapma Değerleri

\begin{tabular}{|c|c|c|c|c|c|c|c|c|c|c|}
\hline Örneklem No & 1 & 2 & 3 & 4 & 5 & 6 & 7 & 8 & 9 & 10 \\
\hline$\overline{\bar{x}}$ Değeri & 15.186 & 15.184 & 15.200 & 15.195 & 15.191 & 15.175 & 15.187 & 15.175 & 15.206 & 15.214 \\
\hline R Değeri & 0.096 & 0.079 & 0.120 & 0.121 & 0.098 & 0.114 & 0.179 & 0.106 & 0.184 & 0.183 \\
\hline$\sigma_{\overline{\bar{x}}}$ Değeri & 0.0409 & 0.0373 & 0.0455 & 0.0524 & 0.0442 & 0.0471 & 0.0749 & 0.0467 & 0.0672 & 0.0737 \\
\hline Örneklem No & 11 & 12 & 13 & 14 & 15 & 16 & 17 & 18 & 19 & 20 \\
\hline$\overline{\bar{x}}$ Değeri & 15.186 & 15.188 & 15.180 & 15.191 & 15.169 & 15.175 & 15.163 & 15.164 & 15.193 & 15.200 \\
\hline R Değeri & 0.151 & 0.141 & 0.169 & 0.155 & 0.146 & 0.116 & 0.103 & 0.112 & 0.155 & 0.102 \\
\hline$\sigma_{\bar{x}}$ Değeri & 0.0638 & 0.0621 & 0.0788 & 0.0592 & 0.0583 & 0.0434 & 0.0422 & 0.0445 & 0.0549 & 0.0396 \\
\hline Örneklem No & 21 & 22 & 23 & 24 & 25 & 26 & 27 & 28 & 29 & 30 \\
\hline$\overline{\bar{x}}$ Değeri & 15.196 & 15.184 & 15.174 & 15.196 & 15.188 & 15.207 & 15.196 & 15.213 & 15.202 & 15.210 \\
\hline R Değeri & 0.130 & 0.074 & 0.109 & 0.146 & 0.067 & 0.114 & 0.134 & 0.138 & 0.046 & 0.084 \\
\hline$\sigma_{\overline{\bar{x}}}$ Değeri & 0.0462 & 0.0262 & 0.0458 & 0.0573 & 0.0347 & 0.0436 & 0.0485 & 0.0512 & 0.0185 & 0.0350 \\
\hline Örneklem No & 31 & 32 & 33 & 34 & 35 & 36 & 37 & 38 & 39 & 40 \\
\hline $\bar{x}$ Değeri & 15.201 & 15.209 & 15.196 & 15.198 & 15.197 & 15.186 & 15.196 & 15.172 & 15.173 & 15.158 \\
\hline R Değeri & 0.092 & 0.146 & 0.140 & 0.112 & 0.125 & 0.175 & 0.279 & 0.203 & 0.206 & 0.147 \\
\hline$\sigma_{\bar{x}}$ Değeri & 0.0367 & 0.0587 & 0.0500 & 0.0481 & 0.0516 & 0.0714 & 0.1107 & 0.0846 & 0.0910 & 0.0543 \\
\hline Örneklem No & 41 & 42 & 43 & 44 & 45 & 46 & 47 & 48 & 49 & $\mathbf{5 0}$ \\
\hline$\overline{\bar{x}}$ Değeri & 15.166 & 15.145 & 15.156 & 15.147 & 15.133 & 15.167 & 15.196 & 15.178 & 15.167 & 15.183 \\
\hline R Değeri & 0.118 & 0.122 & 0.134 & 0.081 & 0.230 & 0.112 & 0.127 & 0.083 & 0.111 & 0.095 \\
\hline$\sigma_{\overline{\bar{\gamma}}}$ Değeri & 0.0461 & 0.0490 & 0.0542 & 0.0395 & 0.0844 & 0.0445 & 0.0500 & 0.0299 & 0.0476 & 0.0373 \\
\hline
\end{tabular}

Anakütle ortalaması ve standart sapması bilinmediği ve kontrol değişkenleri için kullanılan faktör değerleri tablosu yardımı ile $\mathrm{A}_{2}=0,577$ olarak alındığı zaman $\bar{x}$ kontrol grafiği parametreleri ve hesaplanan değerler Şekil 2'de gösterilmiştir. 

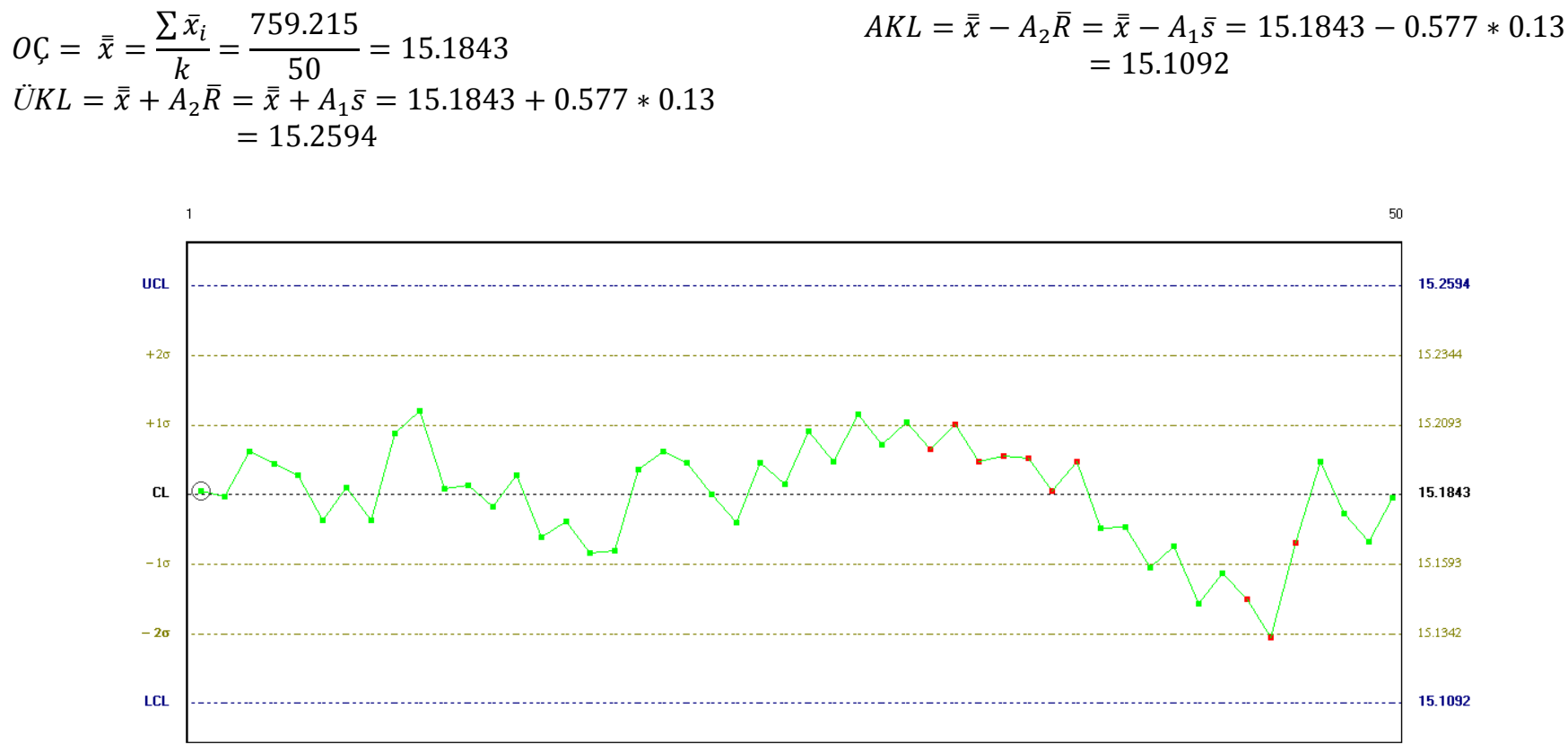

Şekil 2. Ortalamalar İçin Standart Shewart Kontrol Grafiğgi

Seçilen 50 örnekleme ait Shewart kontrol grafiği standart kullanım yöntemi ile hesaplanmıştır. Kontrol limitleri hesaplanırken 3 standart sapmalık ayrılışlar dikkate alınmıştır. Gösterilen kontrol grafiği sonucu olarak üretim sürecinin kontrol altında olduğu gözlemlenmiştir. 50 örneklem değerinden hiçbirinin üst ve alt kontrol limitleri dışında olmadığı gösterilmiştir.

\subsubsection{Cusum Kontrol Grafiği Uygulaması}

Cusum (kümülatif toplam) kontrol grafiği parametreleri; $\mathrm{S}_{\mathrm{i}}=$ i'nci birikimli değer, $\bar{x}_{j}=$ j'inci örneğin aritmetik ortalaması ve $k=\overline{\bar{x}}$ da örneklem ortalaması olarak alınırsa 11 ve 12 numaralı formüller yardımı ile; Cusum kontrol grafiği için hesaplanan örneklemlere ait ortalama değerler, örneklem ortalamasindan sapmalar ve örneklem ortalamasından sapmaların birikimli değerleri Tablo 3 'te gösterilmiştir.

Tablo 3. Cusum Kontrol Grafiği İçin Hesaplanan Değerler

\begin{tabular}{|c|c|c|c|c|c|c|c|c|c|c|}
\hline Örneklem No & $\mathbf{1}$ & $\mathbf{2}$ & $\mathbf{3}$ & $\mathbf{4}$ & $\mathbf{5}$ & $\mathbf{6}$ & $\mathbf{7}$ & $\mathbf{8}$ & $\mathbf{9}$ & $\mathbf{1 0}$ \\
\hline $\boldsymbol{x}_{\boldsymbol{i}}$ & 15.1858 & 15.1836 & 15.2000 & 15.1952 & 15.1914 & 15.1752 & 15.1868 & 15.1752 & 15.2062 & 15.2142 \\
\hline $\boldsymbol{x}_{\boldsymbol{i}}-\overline{\boldsymbol{x}}$ & 0.0015 & -0.0007 & 0.0157 & 0.0109 & 0.0071 & -0.0091 & 0.0025 & -0.0091 & 0.0219 & 0.0299 \\
\hline $\boldsymbol{S}_{\boldsymbol{i}}$ & 0.0015 & 0.0008 & 0.0164 & 0.0273 & 0.0344 & 0.0253 & 0.0278 & 0.0187 & 0.0405 & 0.0704 \\
\hline Örneklem No & $\mathbf{1 1}$ & $\mathbf{1 2}$ & $\mathbf{1 3}$ & $\mathbf{1 4}$ & $\mathbf{1 5}$ & $\mathbf{1 6}$ & $\mathbf{1 7}$ & $\mathbf{1 8}$ & $\mathbf{1 9}$ & $\mathbf{2 0}$ \\
\hline $\boldsymbol{x}_{\boldsymbol{i}}$ & 15.1864 & 15.1876 & 15.1798 & 15.1912 & 15.1690 & 15.1748 & 15.1632 & 15.1642 & 15.1932 & 15.1996 \\
\hline $\boldsymbol{x}_{\boldsymbol{i}}-\overline{\overline{\boldsymbol{x}}}$ & 0.0021 & 0.0033 & -0.0045 & 0.0069 & -0.0153 & -0.0095 & -0.0211 & -0.0201 & 0.0089 & 0.0153 \\
\hline $\boldsymbol{S}_{\boldsymbol{i}}$ & 0.0725 & 0.0758 & 0.0713 & 0.0781 & 0.0628 & 0.0533 & 0.0322 & 0.0121 & 0.0210 & 0.0362 \\
\hline Örneklem No & $\mathbf{2 1}$ & $\mathbf{2 2}$ & $\mathbf{2 3}$ & $\mathbf{2 4}$ & $\mathbf{2 5}$ & $\mathbf{2 6}$ & $\mathbf{2 7}$ & $\mathbf{2 8}$ & $\mathbf{2 9}$ & $\mathbf{3 0}$ \\
\hline $\boldsymbol{x}_{\boldsymbol{i}}$ & 15.1958 & 15.1842 & 15.1744 & 15.1958 & 15.1882 & 15.2072 & 15.1962 & 15.2130 & 15.2022 & 15.2104 \\
\hline $\boldsymbol{x}_{\boldsymbol{i}}-\overline{\overline{\boldsymbol{x}}}$ & 0.0115 & -0.0001 & -0.0099 & 0.0115 & 0.0039 & 0.0229 & 0.0119 & 0.0287 & 0.0179 & 0.0261 \\
\hline $\boldsymbol{S}_{\boldsymbol{i}}$ & 0.0477 & 0.0476 & 0.0377 & 0.0492 & 0.0530 & 0.0759 & 0.0878 & 0.1165 & 0.1344 & 0.1604 \\
\hline Örneklem No & $\mathbf{3 1}$ & $\mathbf{3 2}$ & $\mathbf{3 3}$ & $\mathbf{3 4}$ & $\mathbf{3 5}$ & $\mathbf{3 6}$ & $\mathbf{3 7}$ & $\mathbf{3 8}$ & $\mathbf{3 9}$ & $\mathbf{4 0}$ \\
\hline $\boldsymbol{x}_{\boldsymbol{i}}$ & 15.2008 & 15.2094 & 15.1960 & 15.1982 & 15.1974 & 15.1858 & 15.1962 & 15.1722 & 15.1728 & 15.1582 \\
\hline $\boldsymbol{x}_{\boldsymbol{i}}-\overline{\boldsymbol{x}}$ & 0.0165 & 0.0251 & 0.0117 & 0.0139 & 0.0131 & 0.0015 & 0.0119 & -0.0121 & -0.0115 & -0.0261 \\
\hline $\boldsymbol{S}_{\boldsymbol{i}}$ & 0.1769 & 0.2020 & 0.2137 & 0.2276 & 0.2407 & 0.2421 & 0.2540 & 0.2419 & 0.2304 & 0.2043 \\
\hline Örneklem No & $\mathbf{4 1}$ & $\mathbf{4 2}$ & $\mathbf{4 3}$ & $\mathbf{4 4}$ & $\mathbf{4 5}$ & $\mathbf{4 6}$ & $\mathbf{4 7}$ & $\mathbf{4 8}$ & $\mathbf{4 9}$ & $\mathbf{5 0}$ \\
\hline $\boldsymbol{x}_{\boldsymbol{i}}$ & 15.1658 & 15.1452 & 15.1562 & 15.1466 & 15.1328 & 15.1670 & 15.1962 & 15.1776 & 15.1672 & 15.1830 \\
\hline $\boldsymbol{x}_{\boldsymbol{i}}-\overline{\boldsymbol{x}}$ & -0.0185 & -0.0391 & -0.0281 & -0.0377 & -0.0515 & -0.0173 & 0.0119 & -0.0067 & -0.0171 & -0.0013 \\
\hline $\boldsymbol{S}_{\boldsymbol{i}}$ & 0.1857 & 0.1466 & 0.1185 & 0.0808 & 0.0293 & 0.0120 & 0.0238 & 0.0171 & 0.0000 & -0.0013 \\
\hline
\end{tabular}

Eğer $\bar{x}_{i}$ 'nin standart sapması $\sigma_{\bar{x}}$ ile gösterilir, literatürdeki benzer çalışmalarda olduğu gibi $\alpha=0,01$ ve $\beta=0$ olarak kabul edilir bir seviyede tutulursa, kontrol değişkenleri için kullanılan faktör değerleri yardımı ile $\mathrm{d}_{2}=2,326$ olarak alınır ve $\mathrm{V}$ maskesi kollarının eğimini veren değer yani standart ayrılışları dikkate alan $\mathrm{k}=1$ olarak alınırsa $\mathrm{V}$ maskesi parametreleri;

$\sigma=\frac{\bar{R}}{d_{2}}=\frac{0.2540}{2.326}=0.1092$

$$
\begin{aligned}
& \Delta=k \sigma=\sigma=0.1092 \\
& \sigma_{\bar{x}}=\frac{\sigma}{\sqrt{n-1}}=\frac{0.1092}{\sqrt{50-1}}=0.0363 \\
& \delta^{2}=\left(\frac{\Delta}{\sigma_{\bar{x}}}\right)^{2}=\left(\frac{0.1092}{0.0363}\right)^{2}=49 \\
& d=-2 \frac{\operatorname{In} \alpha}{\delta^{2}}=-2 \frac{\operatorname{In} 0.01}{49}=0.188 \\
& A=2 \sigma_{\bar{x}}=2 * 0.0363=0.0726
\end{aligned}
$$


$\theta=\tan ^{-1}\left(\frac{\Delta}{2 A}\right)=\tan ^{-1}\left(\frac{0.1092}{2 * 0.0726}\right)=36.9468^{\circ}$

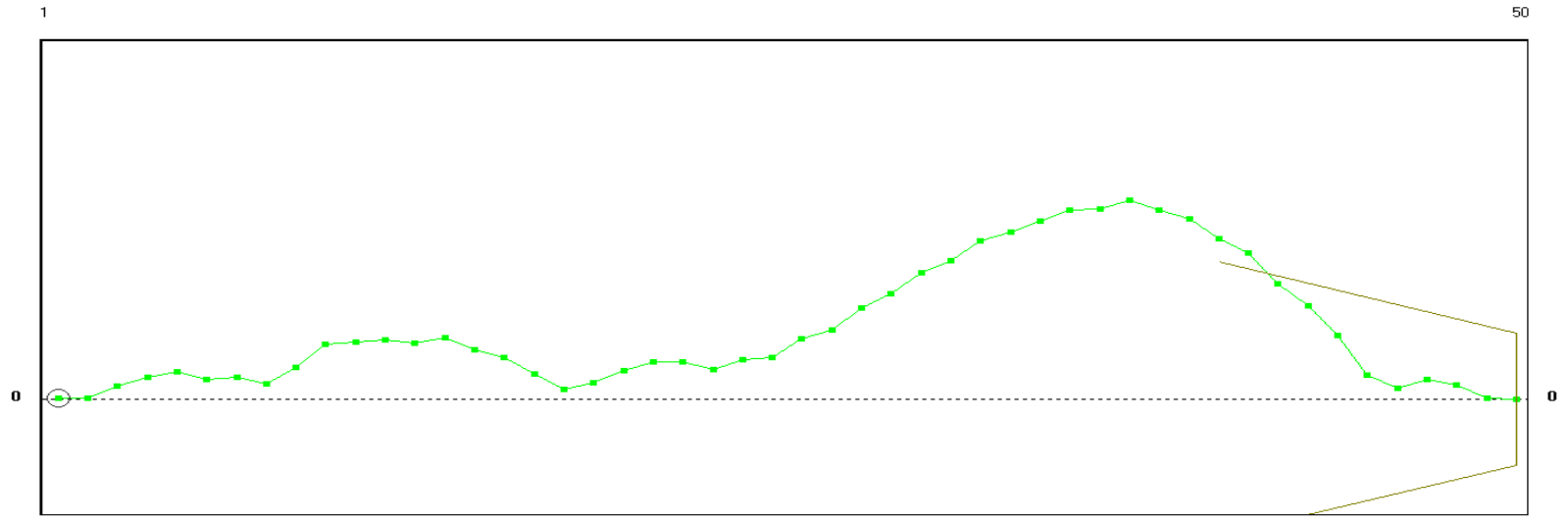

Şekil 3. Ortalamalar İçin Standart Cusum Kontrol Grafiği

Uygulama kapsamında değerlendirilen 50 örnekleme ait Cusum kontrol grafiği literatürdeki yaygın kullanım yöntemi ile hesaplanmıştır. V maskesi hesaplanırken 1 standart sapmalık ayrılışlar dikkate alınmıştır ve Şekil 3 'te ortalamalar için standart Cusum kontrol grafiği gösterilmiştir. Hesaplamalar ve grafik sonucunda Cusum kontrol grafiğine göre üretim süreci kontrol altında olduğu gözlemlenmiştir. Cusum kontrol grafiğine uygulanan $\mathrm{V}$ maskesi sonucu örneklem değerlerinin üst ve alt kontrol limitlerinin dışında olmadığı görülmüştür.

\subsubsection{Ewma Kontrol Grafiği Uygulamas}

Örneklem alt gruplarının hacmi $\mathrm{n}$ ve ortalamaları $\bar{X}_{j}(j=1,2,3, \ldots, t, \ldots, k)$ olmak üzere $\mathrm{t}$ döneminin üstel ağırlıklı hareketli ortalama değerleri, süreçteki büyük ve küçük kaymaların aynı oranda tespiti için örnekleri ağırlıklandırma katsayısı $\lambda=0,5$ olarak alınmıştır ve Eşitlik 22 yardımıyla Ewma kontrol grafiği için hesaplanan ortalamalar ve $\mathrm{Z}$ değerleri Tablo 4'te gösterilmiştir.

Tablo.4 Ewma kontrol grafiği için hesaplanan değerler

\begin{tabular}{|c|c|c|c|c|c|c|c|c|c|c|}
\hline Örneklem No & 1 & 2 & 3 & 4 & 5 & 6 & 7 & 8 & 9 & 10 \\
\hline $\bar{x}_{i}$ Değeri & 15.186 & 15.184 & 15.200 & 15.195 & 15.191 & 15.175 & 15.187 & 15.175 & 15.206 & 15.214 \\
\hline$Z_{i}$ Değeri & 15.1850 & 15.1843 & 15.1922 & 15.1937 & 15.1925 & 15.1839 & 15.1853 & 15.1803 & 15.1932 & 15.2037 \\
\hline Örneklem No & 11 & 12 & 13 & 14 & 15 & 16 & 17 & 18 & 19 & 20 \\
\hline $\bar{x}_{i}$ Değeri & 15.186 & 15.188 & 15.180 & 15.191 & 15.169 & 15.175 & 15.163 & 15.164 & 15.193 & 15.200 \\
\hline$Z_{i}$ Değeri & 15.1951 & 15.1913 & 15.1856 & 15.1884 & 15.1787 & 15.1767 & 15.1700 & 15.1671 & 15.1801 & 15.1899 \\
\hline Örneklem No & 21 & 22 & 23 & 24 & 25 & 26 & 27 & 28 & 29 & 30 \\
\hline $\bar{x}_{i}$ Değeri & 15.196 & 15.184 & 15.174 & 15.196 & 15.188 & 15.207 & 15.196 & 15.213 & 15.202 & 15.210 \\
\hline$Z_{i}$ Değeri & 15.1928 & 15.1885 & 15.1815 & 15.1886 & 15.1884 & 15.1978 & 15.1970 & 15.2050 & 15.2036 & 15.2070 \\
\hline Örneklem No & 31 & 32 & 33 & 34 & 35 & 36 & 37 & 38 & 39 & 40 \\
\hline $\bar{x}_{i}$ Değeri & 15.201 & 15.209 & 15.196 & 15.198 & 15.197 & 15.186 & 15.196 & 15.172 & 15.173 & 15.158 \\
\hline$Z_{i}$ Değeri & 15.2039 & 15.2067 & 15.2013 & 15.1998 & 15.1986 & 15.1922 & 15.1942 & 15.1832 & 15.1780 & 15.1681 \\
\hline Örneklem No & 41 & 42 & 43 & 44 & 45 & 46 & 47 & 48 & 49 & $\mathbf{5 0}$ \\
\hline $\bar{x}_{i}$ Değeri & 15.166 & 15.145 & 15.156 & 15.147 & 15.133 & 15.167 & 15.196 & 15.178 & 15.167 & 15.183 \\
\hline$Z_{i}$ Değeri & 15.1669 & 15.1561 & 15.1561 & 15.1514 & 15.1421 & 15.1545 & 15.1754 & 15.1765 & 15.1718 & 15.1774 \\
\hline
\end{tabular}

Grafiklerin kontrol sınırlarının hesaplanmasında standart sapma kullanılacağından $Z_{t}$ değerinin standart sapması aşağıda hesaplanmıştır.

$\bar{S}=\frac{\bar{R}}{d_{2}}=\frac{0,0814}{2,326}=0.035$

$\sigma_{Z_{t}}=\bar{s} \sqrt{\frac{\lambda}{(2-\lambda) n}}=0.035 \sqrt{\frac{0.5}{(2-0.5) 50}}=0.0029$

Ana kütle ortalamasının ve standart sapmasının bilinmemesi durumunda kontrol sınırları aşağıdaki eşitliklerde gösterilmiştir.
$\ddot{\mathrm{U}} K L=\overline{\bar{x}}+A_{2} \bar{R} \sqrt{\frac{\lambda}{(2-\lambda)}}$

$\ddot{\mathrm{U}} K L=15.1843+0.577 * 0.0814 \sqrt{\frac{0.5}{(2-0.5)}}=15.2114$

$O C=\overline{\bar{x}}=15.1843$

$A K L=\overline{\bar{x}}-A_{2} \bar{R} \sqrt{\frac{\lambda}{(2-\lambda)}}$

$A K L=15.1843-0.577 * 0.0814 \sqrt{\frac{0.5}{(2-0.5)}}=15.1572$ 


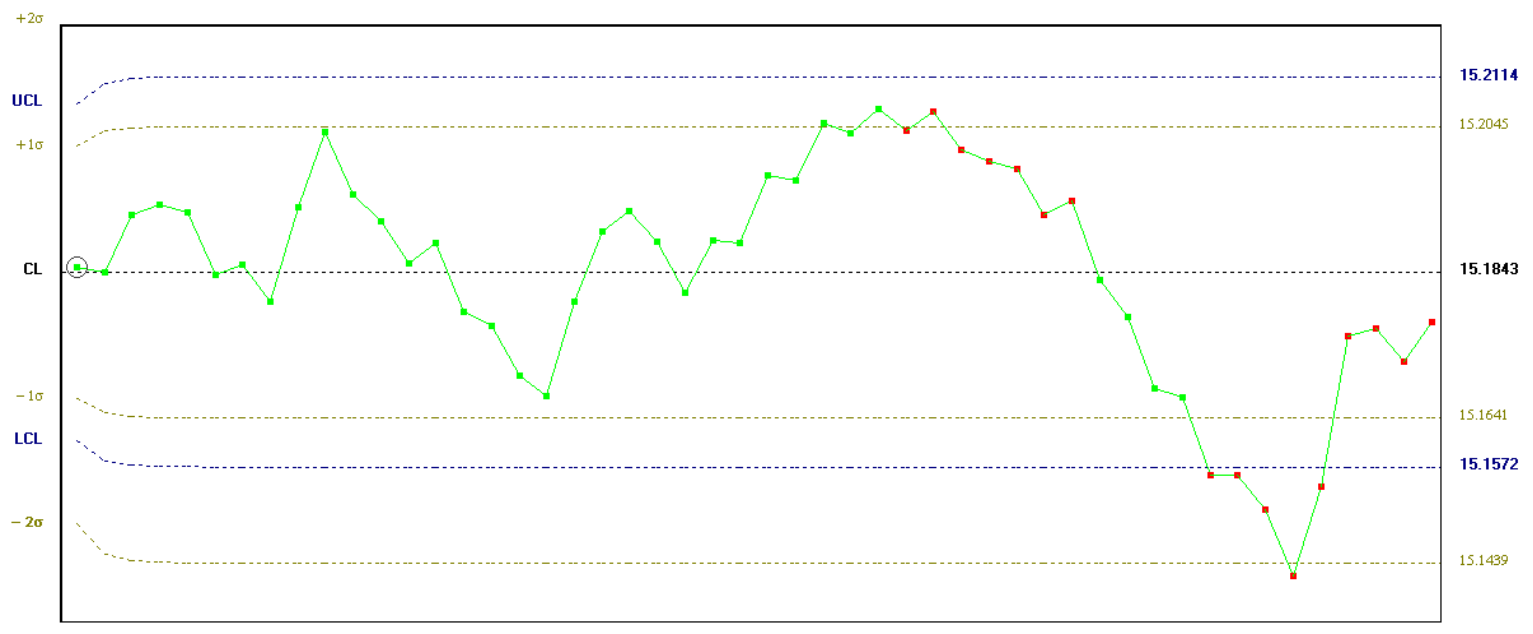

Şekil 4. Ortalamalar İçin Standart Ewma Kontrol Grafiği

Ortalamalar için hesaplanan Ewma kontrol grafiği yaygın kullanım yöntemi ile hesaplanmıştır. Üst ve alt kontrol limitleri hesaplanırken 1.5 standart sapmalık ayrılışlar kullanılmıştır ve ortalamalar için Ewma kontrol grafiği Şekil 4'te gösterilmiştir.

Şekilde gösterilen Ewma kontrol grafiği sonucu üretim sürecinin kontrol altında olmadığı görülmüştür. Örneklem 42 ve 46 arasındaki değerlerin alt kontrol limiti sınırını aştığı ve süreci düzeltici tedbirlerin alınması gerektiği sonucuna varılmıştır.

\subsubsection{Ortalamalar İçin Kontrol Grafiklerinin Karşılaştırılması}

Uygulamada gösterilen kontrol grafiği türleri genel kabul görmüş kullanım yöntemleri ile hesaplanmıştır. Ancak kontrol grafikleri arasında kıyaslama yapılabilmesi için ortak koşulların sağlanması gerekmektedir. $\mathrm{Bu}$ nedenle kontrol grafikleri aynı standart sapmalık ayrılışlar dikkate alınarak tekrar çizilecektir. $\mathrm{Bu}$ sayede grafiklerin karşılaştırılması daha doğru ve kıyaslama yapılması için daha uygun koşullar sağlanmış olacaktır.

Ortak kıyaslamanın yapılabilmesi için kontrol grafiği türleri için ortak bir standart sapmanın belirlenmesi gerekmektedir. Kullanım kolaylığı ve süreci daha iyi olarak değerlendiren Cusum kontrol grafiklerinde kullanılan 1 standart sapmalık ayrılışlar dikkate alınacaktır. Shewart kontrol grafiklerinde ele alınan 3 standart sapmalık ayrılışlar 1 standart sapma olarak değerlendirilecektir ve Ewma kontrol grafiklerinde de 1.5 standart sapmalık ayrılışlar 1 standart sapma olarak değerlendirilecektir.

- Shewart Kontrol Grafiği Uygulaması

Örnekleme ait ortalamalar, değişim aralığı değerleri ve standart sapma değerleri Microsoft Excel yardımı ile hesaplanmış ve Tablo 2'de gösterilmiştir. Kontrol sınırları standart Shewart kontrol grafiğinde 3 standart sapma ile hesaplandığı için kontrol sınırlarının değişkeni (1/3) ile çarpılarak 1 standart sapmalık ayrılışlar hesaplanmış ve 1 ve 5 arası numaralı eşitlikler yardımı ile çizilmiştir.

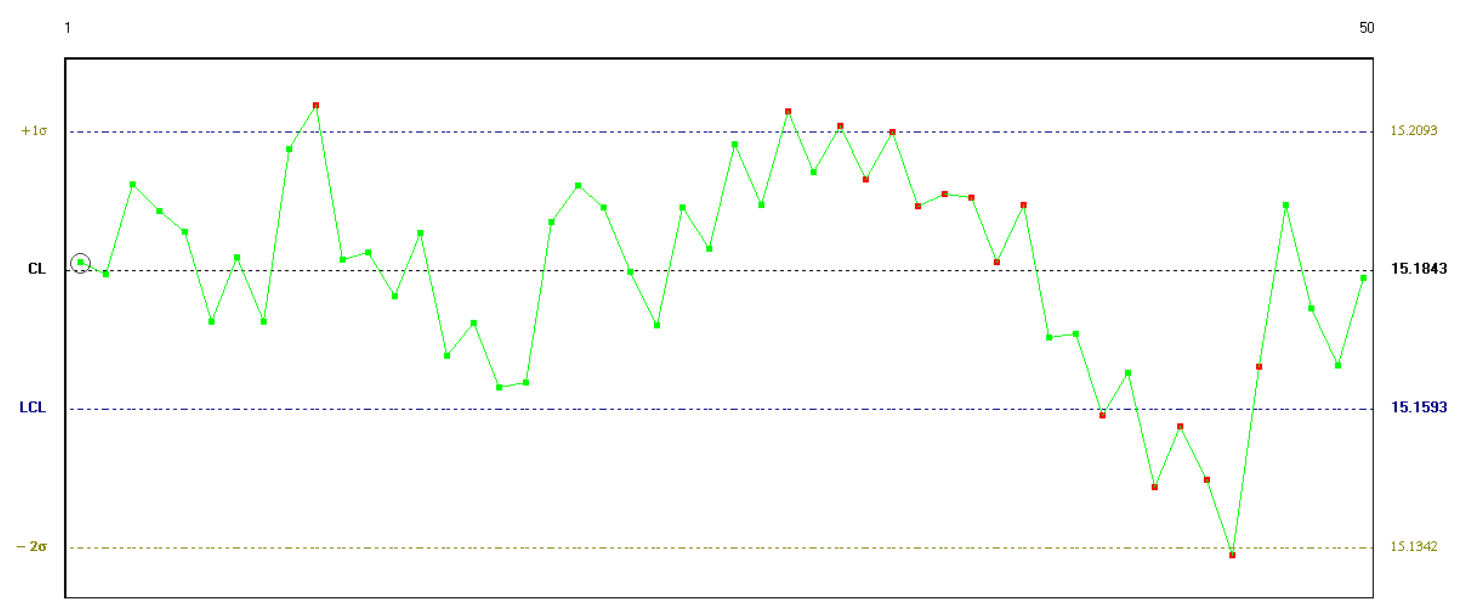

Şekil 5. Ortalamalar İçin Shewart Kontrol Grafiği

Kıyaslamaların yapılabilmesi için oluşturan 1 standart sapmalık ayrılışlara sahip Shewart kontrol grafiği Şekil 5 'te gösterilmiştir. Yeni hesaplamalar sonucu sürecin kontrol altında olmadığı sonucuna varılmıştır. Sürecin ciddi sorunlara işaret ettiği hem alt hem de üst sınırların aşıldığı değişkenliğin çok fazla arttığı müdahale edilmesi gerektiği sonucuna varılmıştır.

- Cusum Kontrol Grafiği Uygulaması

Cusum kontrol grafiği parametrelerinde 1 standart sapmalık ayrılışlar dikkate alındığı ve dolayısıyla herhangi bir değişiklik yapılmadığı için Cusum kontrol grafiği Şekil 
3'teki gibidir. Örnekleme ait Cusum kontrol grafiği sonucuna göre sürecin kontrol altında olduğu görülmüştür.
- Ewma Kontrol Grafiği Uygulamasi

Ortak standart sapmalar için hazırlanan 1 standart sapmalık ayrılışların dikkate alındığı Ewma kontrol grafiği 22 ve 27 arasındaki eşitlikler yardımı ile tekrar hesaplanmıştır.

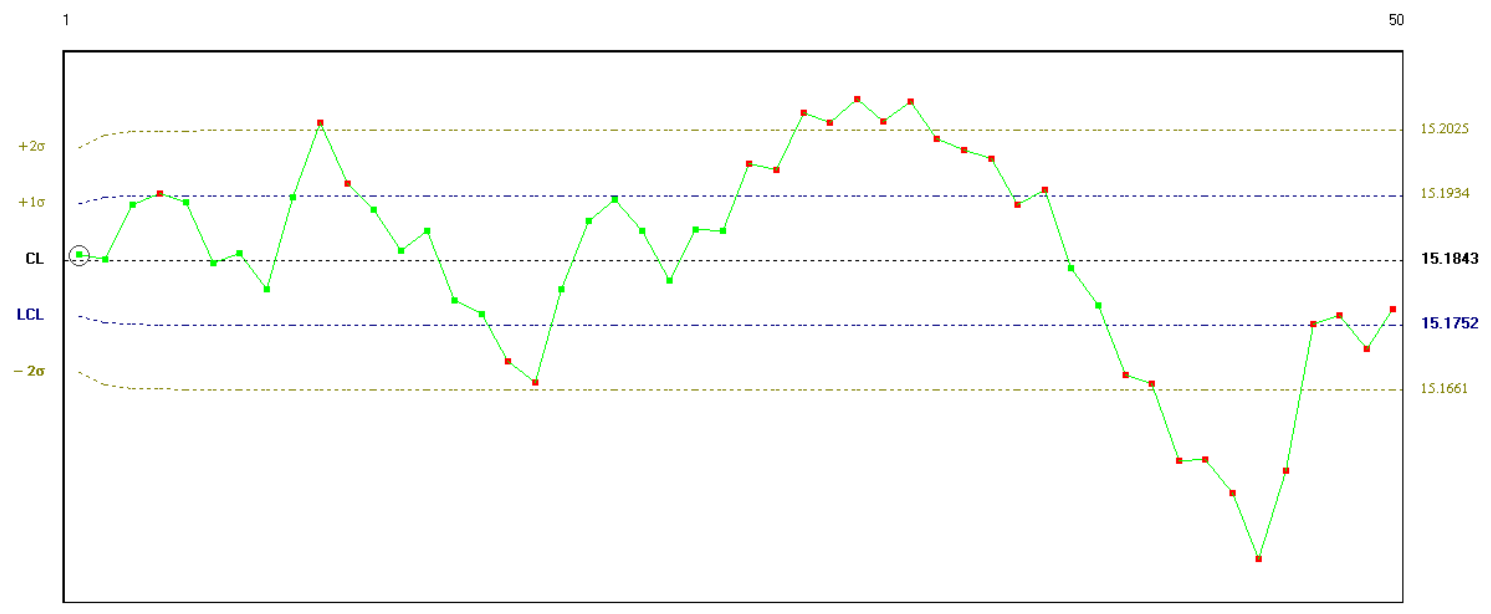

Şekil 6. Ortalamalar İçin Ewma Kontrol Grafiği

Şekil 6'da gösterilen Ewma kontrol grafiği sonucu yine üretim sürecinin kontrol altında olmadığ 1 görülmüştür. Ewma kontrol grafiği ile süreçteki 24 noktanın kontrol dışında olduğu ve süreçteki örneklemlerin neredeyse yarısının kontrol dişında olduğu görülmüştür. Ewma kontrol grafiğine göre süreç için çok fazla düzeltici önlemin alınması gerektiği veya süreçte çok büyük değişiklikler yapılması gerektiği aşikardır. Tablo 5'te kontrol grafikleri türleri için karşılaştırmalara yer verilmiştir.

Tablo.5 Farklı kontrol grafiği türleri için kontrol grafiği kıyaslaması

\begin{tabular}{|c|c|c|c|}
\hline Ortalamalar & \multicolumn{3}{|c|}{ Kontrol Grafiği Türü } \\
\hline $\begin{array}{c}\text { Standart Sapma } \\
\text { Derecesi }\end{array}$ & Shewart & Cusum & Ewma \\
\hline $\begin{array}{l}\text { Temel Standart } \\
\text { Sapma Değerleri } \\
\text { Için; }\end{array}$ & $\begin{array}{l}3 \text { Standart sapmalık ayrılışlar için } \\
\text { süreç kontrol altındadır. }\end{array}$ & $\begin{array}{l}1 \text { Standart sapmalık } \\
\text { ayrılışlar için süreç } \\
\text { kontrol altındadır. }\end{array}$ & $\begin{array}{l}\text { 1.5 Standart sapmalık ayrılışlar için süreç kontrol altında } \\
\text { değildir. } \\
\text { (Kontrol dışı örneklem değerleri; } 42,43,44,45 \text { ve } 46 \text { ) }\end{array}$ \\
\hline $\begin{array}{l}1 \text { Standart Sapmalık } \\
\text { Ayrılışlar İçin }\end{array}$ & $\begin{array}{l}\text { 1 Standart sapmalık ayrılışlar için } \\
\text { süreç kontrol altında değildir. } \\
\text { (Kontrol dışı örneklem değerleri; } 10 \text {, } \\
28,30,32,40,42,43,44 \text { ve } 45 \text { ) }\end{array}$ & $\begin{array}{l}1 \text { Standart sapmalık } \\
\text { ayrılışlar için süreç } \\
\text { kontrol altındadır. }\end{array}$ & $\begin{array}{l}\text { 1 Standart sapmalık ayrılışlar için süreç kontrol altında } \\
\text { değildir. } \\
\text { (Kontrol diş1 örneklem değerleri; 4, 10, 11, 17, 18, 26, 27, 28, } \\
29,30,31,32,33,34,35,37,40,41,42,43,44,45,46 \text { ve 49) }\end{array}$ \\
\hline
\end{tabular}

Değerlendirmeler sonucunda Cusum kontrol grafiğinin süreç hakkında diğer grafik türlerinden daha olumlu sonuçlar verdiği görülmektedir. Ewma kontrol grafiğinin ise diğer grafik türleri arasında süreci en olumsuz şekilde değerlendiren grafik türü olduğu gözlemlenmiştir. Kullanılan grafik türleri içerisinde maksimum faydayı sağlayacak grafik türünü belirlemek için değişim aralığ grafik türünün de yapılması doğru karar verilmesini sağlayacaktır.

\subsection{Değişim Aralığı İçin Kontrol Grafikleri}

Farklı türdeki değişim aralığı kontrol grafikleri ile hesaplanacak kıyaslamanın doğru şekilde yapılabilmesi için 1 standart sapmalık ayrılışlar dikkate alınmıştır.

\subsubsection{Shewart Kontrol Grafiği Uygulaması}

Ele alınan örneklem için her biri $n=1$ birimden oluşan $\mathrm{m}=50$ tane örnek alındığında, $\mathrm{R}_{1}, \mathrm{R}_{2}, \ldots, \mathrm{R}_{\mathrm{m}}$ bu örneklerin değişim aralıkları olmak üzere değişim aralıkları ortalamaları Tablo 2'de gösterilmiştir. Eşitlik 7 ve 10 arasındaki formüller yardımı ile değişim aralığı için standart Shewart kontrol grafiği hesaplanmıştır. 


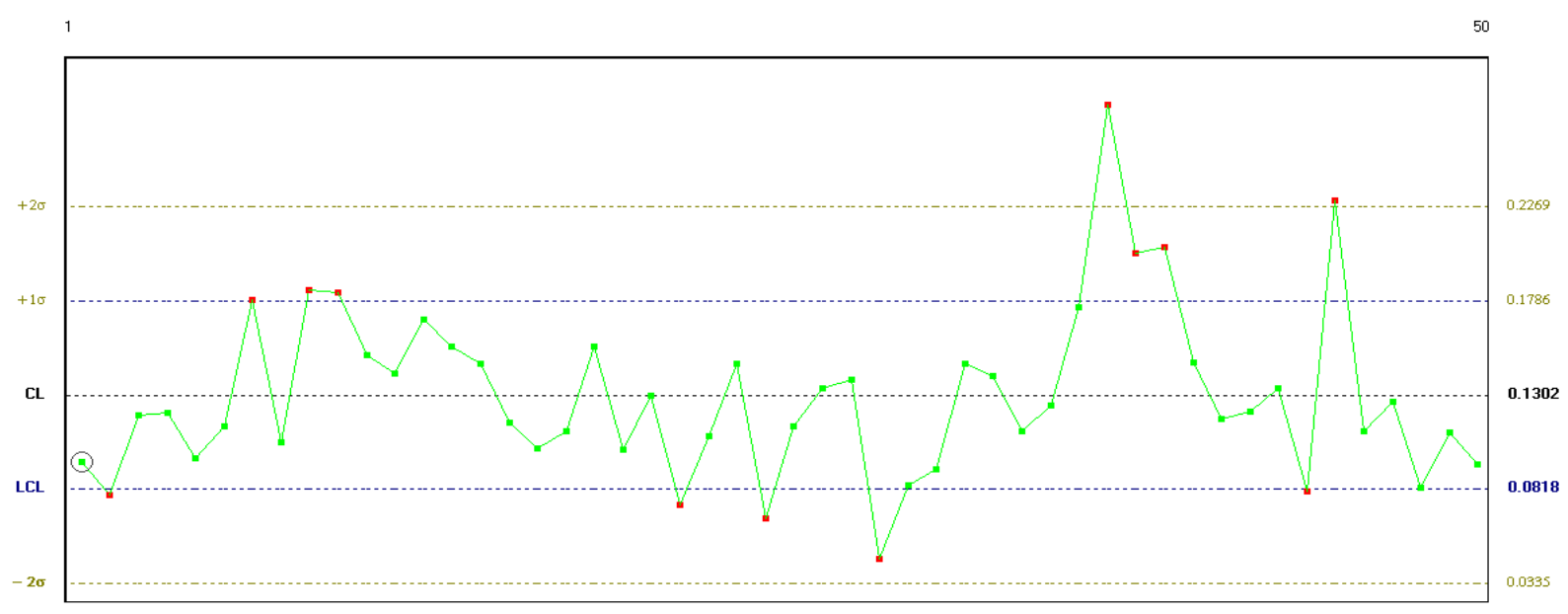

Şekil 7. Değişim Aralı̆̆ İçin Shewart Kontrol Grafiği

Shewart kontrol grafiği türünün değişim aralığı için hesaplanan kontrol grafiği Şekil 7'de gösterilmiştir. Karşılaştırmalara esas oluşturması açısından 1 standart sapmalık ayrılışlar dikkate alınmıştır. Şekil 7 'de gösterilen Shewart kontrol grafiği sonucu üretim sürecinin kontrol altında olmadığı tespit edilmiştir. Shewart kontrol grafiği ile süreçteki 11 noktanın kontrol dışında olduğu ve süreçteki değişim miktarının değişkenliği gözler önüne serilmiştir. Shewart değişimler için kontrol grafiğine göre süreç çok fazla değişkenliğe sahiptir ve değişkenliğin nedenlerini azaltacak önlemler alınmalıdır.

\subsubsection{Cusum Kontrol Grafiği Uygulaması}

Değişim aralığı Cusum kontrol grafiği ortalamalar için hesaplanan yöntemle aynı olduğundan dolayı $n=1$ değişikliği ve $m=50$ olmak üzere Eşitlik 11 ve 21 arasındaki formüller yardımı ile değişim aralıkları için 1 standart sapmalık ayrılışlar dikkate alınarak çizilmiştir.

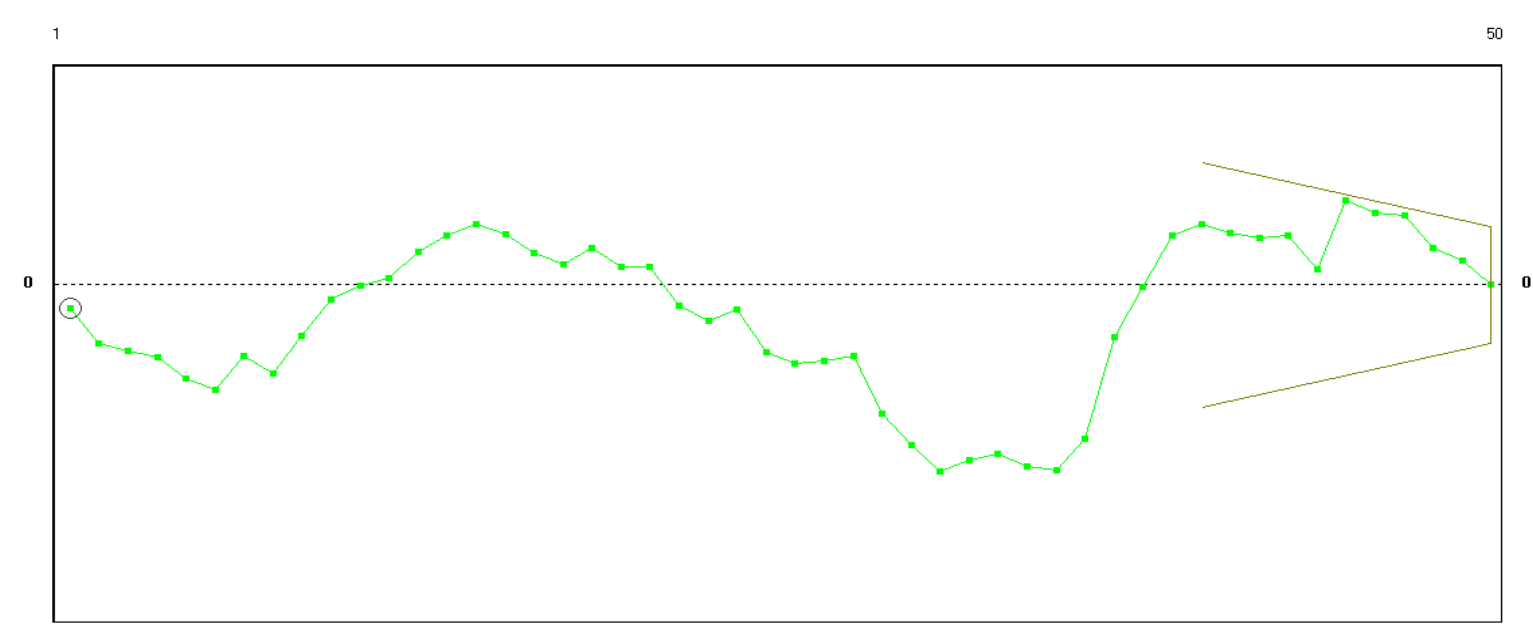

Şekil 8. Değişim Aralığı İçin Cusum Kontrol Grafiği

Cusum kontrol grafiği değişim aralığı için diğer kontrol grafiği türleriyle kıyaslanabilmesi için 1 standart sapmalık ayrılışlar dikkate alınarak çizilmiştir. Şekil 8'de gösterilen Cusum kontrol grafiği sonucu üretim sürecinin kontrol altında olduğu tespit edilmiştir. Şekilden de anlaşılacağı gibi değişimler için Cusum kontrol grafiğine göre süreç çok fazla değişkenliğe sahiptir ancak kontrol altındadır. Değişkenliği azaltacak herhangi bir önlemin alınmasına gerek yoktur.

\subsubsection{Ewma Kontrol Grafiği Uygulaması}

Değişim aralığı Ewma kontrol grafiği de ortalamalar için hesaplanan yöntemle aynı olduğundan dolayı $n=1$ değişikliği ve $\mathrm{m}=50$ olmak üzere Eşitlik 22 ve 27 arasındaki formüller yardımı ile değişim aralıkları için karşılaştırmalara esas oluşturması açısından 1 standart sapmalık ayrılışlar dikkate alınarak çizilmiştir. 


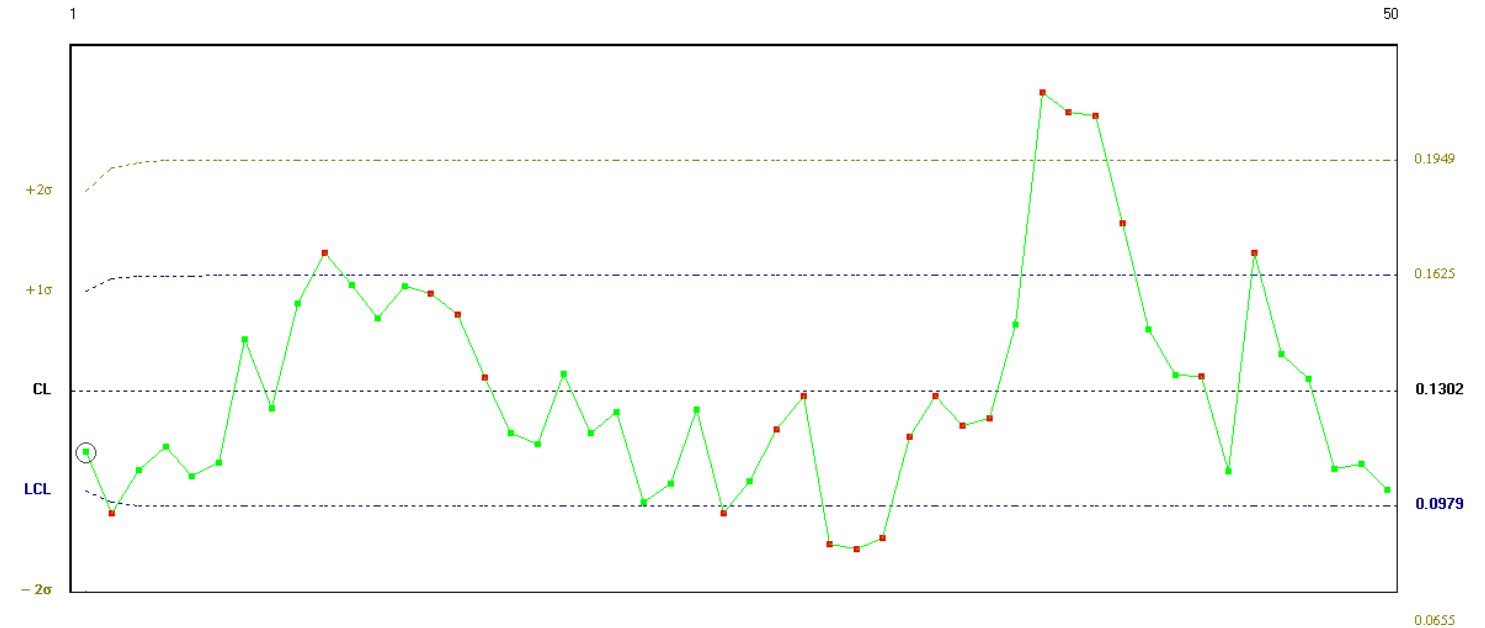

Şekil 9. Değişim Aralığı İçin Ewma Kontrol Grafiği

Şekil 9'da gösterilen Ewma kontrol grafiği sonucu üretim sürecinin kontrol altında olmadığı tespit edilmiştir. Ewma kontrol grafiği ile süreçteki 11 noktanın kontrol dışında olduğu ve süreçteki değişim miktarının değişkenliği gözler önüne serilmiştir. Ewma değişimler için kontrol grafiğine göre süreç çok fazla değişkenliğe sahiptir ve değişkenliğin nedenlerini azaltacak önlemler alınmalıdır.

\subsubsection{Değişim Aralığı İçin Kontrol Grafiklerinin} Karşılaştırılması

Ortalamalar için kontrol grafiklerinin kıyaslanması ile grafik türleri ve süreç hakkında net bilgi sahibi olunamamıştır. Bu nedenle değişim aralığı grafik türleri de inceleme kapsamında alınmıştır. Değişim aralığı grafik türleri karşılaştırma yapılabilmesi için 1 standart sapmalık ayrılışlar göz önünde bulundurularak yapılmıştır. Değişim aralığı grafik türlerinin kıyaslanması ortalamalar için uygun olan grafik türünün belirlenmesine yardımcı olacaktır. Tablo 6'da farklı kontrol grafiği türleri için kullanılan değişim aralığı kontrol grafikleri karşılaştırma sonucuna yer verilmiştir.

Tablo 6. Değişim Aralığı İçin Farklı Kontrol Grafiği Sonuçları

\begin{tabular}{|c|c|c|c|}
\hline Değişim aralığı & Ko & atrol Grafiği Türü & \\
\hline Std Sapma Derecesi & Shewart & Cusum & Ewma \\
\hline $\begin{array}{l}1 \text { Standart Sapmalık } \\
\text { Ayrllışlar İçin }\end{array}$ & $\begin{array}{l}\text { Süreç kontrol altında değildir. (Kontrol dışı } \\
\text { örneklem değerleri; } 7,9,10,22,25,29,37 \text {, } \\
38,39,44 \text { ve } 45 \text { ) }\end{array}$ & Süreç kontrol altındadır. & $\begin{array}{l}\text { Süreç kontrol altında değildir. } \\
\text { (Kontrol dış1 örneklem değerleri; } 2,10,25,29,30 \text {, } \\
31,37,38,39,40 \text { ve } 45 \text { ) }\end{array}$ \\
\hline
\end{tabular}

Değerlendirmeler sonucunda Cusum kontrol grafiğinin, ortalamalar için olan kontrol grafiklerindeki gibi aynı yani süreç hakkında değişimin kontrol altında olduğu sonucunu verdiği görülmektedir.

Ewma kontrol grafiği ve Shewart kontrol grafikleri değişim aralığ 1 için yaklaşık olarak aynı sonuçları vermiştir. Kontrol dişı bulunan noktalar arasında 10, 25, 29, 37, 3839 ve 45 numaralı örneklem alt grup gözlem değerleri her iki grafik türünde de kontrol dışı olarak saptanmıştır. Ayrıca kontrol dışı noktaların sayısı her iki kontrol grafiği türünde de aynı sayıda olduğu görülmüştür.

\section{Sonuç}

Seçilen örneklem sonucu bakır mamulü direnç miktarlarının değişimini gösteren Shewart, Cusum ve Ewma kontrol grafikleri uygulama bölümünde ele alınmıştır. Çalışmada elde edilen ortalamalar için kontrol grafikleri karşılaştırıldığında; standart Shewart ve Cusum kontrol grafiklerine göre sürecin kontrol altında olduğu ve aynı sonucu verdiği tespit edilmiştir. Ancak standart Ewma kontrol grafiği diğer grafik türlerinden farklı olarak sürecin kontrol dişı olduğu sonucunu vermiştir.

Ortalamalar için hesaplanan standart kontrol grafiklerinde 1 standart sapmalık ayrılışlar dikkate alındığında, Cusum kontrol grafiği 1 standart sapmalık ayrılışlar dikkate aldığı için sonuçta bir değişme olmamış ve süreç kontrol altında olarak tespit edilmiştir. Shewart ve Ewma kontrol grafikleri süreci kontrol dışı olarak saptamıştır. Shewart kontrol grafiklerinde 9 ölçüm değeri ve Ewma kontrol grafiklerinde ise 18 ölçüm değeri kontrol dişı olarak hesaplanmıştır. Ortalamalar için bulunan bu değerlendirmeler maksimum fayda sağlayacak grafik türünün belirlenmesinde yetersiz kalmıştır.

Çalışma kapsamında sadece ortalamalar ile ele alınan süreç ve uygun kontrol grafiği hakkında karar vermenin yetersiz olacağı kanaatine varılmıştır. $\mathrm{Bu}$ nedenle değişim aralıkları için de kontrol grafiği türleri hesaplanmıştır. Uygun kontrol grafiği türüne karar verilmesini kolaylaştırmak amacıyla değişim aralıkları için hesaplanan kontrol grafiklerinde 1 standart sapmalık ayrılışlar dikkate alınmıştır.

Değişim aralığı için hesaplanan Cusum kontrol grafiğine göre süreçteki değişim kontrol altındadır. Süreçteki değişimi, Shewart ve Ewma kontrol grafikleri Cusum kontrol grafiğinin aksine kontrol dişı olarak değerlendirmiştir. Shewart ve Ewma kontrol grafiklerinin aynı sayıda kontrol dışı gözlem değerine sahip olduğu görülmüştür.

Ewma kontrol grafiklerinin sapma derecelerini birikimli ve ağırlıklı olarak ele alması nedeniyle bu bulgular elde edilmiştir. Ewma kontrol grafiği türünün birbirine bağımlı veya etkilenen süreç çıktıları için uygun olduğu tespit edilmiştir. Ayrıca Shewart kontrol grafiklerinin de gözlem değerlerini birbirinden bağımsız olarak ve diğer kontrol 
grafiklerine kıyasla daha büyük farklılıkları ortaya çıkarmak için uygun olduğu yargısına varılmıştır (Demir, 2008: 36). Cusum kontrol grafiklerinin ise Ewma kontrol grafiğinde olduğu gibi küçük ani değişimler için uygun olduğu ve Ewma kontrol grafiklerine kıyasla daha az ilişskili çıktıları test etmede uygun olacağı sonucuna varılmıştır.

Ewma ve Cusum kontrol grafiklerinin avantajı önceki gözlem değerlerinin kontrol noktalarını etkilemesidir (Oktay, 1994: 130). Ewma kontrol grafiklerinin Cusum kontrol grafiklerinden üstünlüğü hata derecelerini birikimli olarak ele alırken önceki gözlemleri derecelendirmesi veya ağırlıklandırmasıdır. Ancak Cusum kontrol grafiklerinin üstünlüğü de gözlem değerlerini toplama usulü birikimli olarak ele almasidir.

Sonuç olarak Shewart, Ewma ve Cusum kontrol grafikleri arasından seçim yapılırken öncelikli karar verilmesi gereken süreç hakkında gerekli bilgilerin sağlanmasıdır. Ele alınan süreç kapsamında örneklemlerin bağımsız oluşu, paralel olarak işlem görmeleri nedeniyle Shewart kontrol grafiklerinin kullanılması daha uygun olacaktır. Shewart kontrol grafiklerinin seçimi ile işletme uygun hata kontrol düzeyinde üretim sürecini değerlendirebilecektir. İşletme bu sayede istenilen derecede hatalarının kontrol altında olup olmamasını tespit edebilecektir. Örneklem ölçüm değerlerinde hata düzeyi yüksek olan operatörler araştırılıp hata nedenleri azaltılarak, hata düzeyi düşürülmelidir. Firmalar üretim süreçlerine ve çıktıların hata düzeyi hassaslığına göre maksimum fayda sağlayacak kalite kontrol grafiklerini kullanmalıdırlar. $\mathrm{Bu}$ sayede kalite düzeyinin arttırılması sağlanabilecektir.

\section{Kaynaklar}

Abbasi, S. A., Riaz, M. ve Miller, A. (2012), "Enhancing the Performance of Cusum Scale Chart", Computers \& Industrial Engineering, 63(2), 400-409.

Akkurt, M. (2002), Kalite Kontrol Excel Destekli, Birsen Yayinevi, 222 s., İstanbul.

Allen, T. T. (2006), Introduction to Engineering Statistics and Six Sigma, Springer London, 29 s., England.

Baskan, Ş. (1997), İstatistiksel Kalite Kontrolü, Ege Üniversitesi Fen Fakültesi Yayınları, No:159, 68-273 ss., İzmir.

Bostan, H. (2010), "İstatistiksel Proses Kontrol Tekniklerinin Motor Yenileştirme Sürecinde Kullanımı”, Yüksek Lisans Tezi, Balıkesir Üniversitesi, Fen Bilimleri Enstitüsü, Balıkesir.

Chen, K., ve Shaw, Y. (2011), "Applying Back Propagation Network to Cold Chain Temperature Monitoring", Advanced Engineering Informatics, 25(1), 11-22.

Dai, Y., Luo, Y., Li, Z. ve Wang, Z. (2011), "A New Adaptive Cusum Control Chart for Detecting the Multivariate Process Mean", Quality and Reliability Engineering International, 27(7), 877-884.

Demir, Y. (2008), "Shewart, Cusum ve Ewma Kontrol Grafiklerinin Makine Sanayine Uygulanması", Yüksek Lisans Tezi, Yüzüncü Y1l Üniversitesi, Fen Bilimleri Enstitüsü, Van.

Fleischer, J., Gisele, L. ve Matthias, S. (2008), "Statistical Quality Control in Micro Manufacturing Through Multivariate MEwma Chart", CIRP Annals - Manufacturing Technology, 57(1), 521-524.
Han, S. W., Tsui, K., Arijunya, B. and Kim, S. B. (2010), “A Comparison of Cusum, Ewma, and Temporal Scan Statistics for Detection of Increases in Poisson Rates", Quality and Reliability Engineering International, 26(3), 279-289.

Işı̆̆ıı̧̧ok, E. (2012), Toplam Kalite Yönetimi Bakış Açısıyla İstatistiksel Kalite Kontrol, Ezgi Kitabevi, 2. Bask1, 289-308 ss., Bursa.

Maravelakis, P. E. (2012), "Measurement Error Effect on the Cusum Control Chart", Journal of Applied Statistics, 39(2), 323336.

Montgomery, D. C. (2005), Introduction to Statistical Quality Control, Fifth Edition, John Wiley And Sons Inc., 197 s., United States of America.

Nenes, G. (2011), "A New Approach for the Economic Design of Fully Adaptive Control Charts", International Journal of Production Economics, 131(2), 631-642.

Nicolay, C. R., Purkayastha, S., Greenhalgh, A., Benn, J., Chaturvedi, S., Phillips, N. And Darzi, A. (2012). "Systematic Review of the Application of Quality Improvement Methodologies From the Manufacturing Industry to Surgical Healthcare", British Journal of Surgery, 99(3), 324 - 335.

Noorossana, R. and Vaghefi, S. J. M. (2006), "Effect of Autocorrelation on Performance of the M-Cusum Control Chart", Quality And Reliability Engineering International, 22(2), 191-197.

Oktay, E. (1994), "Shewart, Cusum ve Ewma Kontrol Grafiklerinin Şeker Sanayiine Uygulanması Üzerine Bir Deneme”, Doktora Tezi, Atatürk Üniversitesi, Sosyal Bilimler Enstitüsü, Erzurum.

Ou, Y., Wu, Z. ve Tsung, F. (2012), "A comparison Study of Effectiveness and Robustness of Control Charts for Monitoring Process Mean", International Of Production Economics, 135(1), 479-490

Özçil, Abdullah (2014), "Shewart, Cusum ve Ewma Kontrol Grafiklerinin Bir Üretim Işsletmesinde Uygulanması", Yüksek Lisans Tezi, Pamukkale Üniversitesi, Sosyal Bilimler Enstitüsü, Denizli.

Patel, A. K. ve Divecha, J. (2011), "Modified Exponentially Weighted Moving Average (EWMA) Control Chart for an Analytical Process Data", Journal of Chemical Engineering and Materials Science, 2(1), 12-20.

Riaz, M., Abbas, N. ve Does, R. J. M. M. (2011), "Improving the Performance of Cusum Charts", Quality and Reliability Engineering International, 27(4), 415-424.

Russo, S. L., Camargo, M. E. and Fabris, J. P. (2012), Pratical Concepts of Quality Control, Edited by Mohammed Saber Fallah Nezhad, Intech, Rijeka, 36 s., Hirvatistan.

Sun, R. J. ve Kalbfleisch, J. D. (2013), "A Risk-Adjusted O-E Cusum with Monitoring Bands for Monitoring Medical Outcomes", Biometrics, 69(1), 62 - 69 .

Şentürk, S. (2002). "Niceliksel Kalite Kontrol Grafiklerinin Varsayımlarının Sinanması ve Bir Uygulama”, Yüksek Lisans Tezi, Anadolu Üniversitesi, Fen Bilimleri Enstitüsü, Eskişehir.

Topalidou, E. and Psarakis, S. (2009), "Review of Multinomial and Multiattribute Quality Control Charts", Quality And Reliability Engineering International, 25(7), 773-804. 
Trietsch, Dan (1999), Statistical Quality Control - A Loss Minimization Approach, Series On Applied Mathematics, World Scientific Publishing Co. Pte. Ltd., Volume 10, 218 s., Singapore.

Vries, A. D. and Conlin, J. (2005), "A Comparison of the Performance of Statistical Quality Control Charts in a Dairy Production System Through Stochastic Simulation", Agricultural Systems, 84(3), 318-320.

Woodall, W. H. (2006), "The Use of Control Charts in HealthCare and Public-Health Surveillance", Journal of Quality Technology, 38(2), 89-104.

Wu, Z., Yang, M., Khoo, M. B. C. ve Yu, F. (2010), "Optimization Designs and Performance Comparison of Two Cusum Schemes for Monitoring Process Shifts in Mean and Variance", European Journal of Operational Research, 205(1), 136150.

Yang, S., Lin, J. and Cheng, S. W. (2011), "A New Nonparametric Ewma Sign Control Chart", Expert Systems with Applicatios, 38(5), 6239-6243.

Yang, M., Wu, Z., Lee, K. M. and Khoo, M. B. C. (2012), “The $\mathrm{X}$ control chart for Monitoring Process Shifts in Mean and Variance", International Journal of Production Research, 50(3), 893-907.

Yılmaz, H. (2012), "Çok Değişkenli İstatistiksel Süreç Kontrolü: Bir Hastane Uygulaması", Yüksek Lisans Tezi, İstanbul Teknik Üniversitesi, Fen Bilimleri Enstitüsü, İstanbul. 